\title{
The Role of Action Research in Teachers' Professional Development
}

\author{
Jelena Osmanović Zajićt* (D), Anastasija Mamutović1 (D), Jelena Maksimović1 (D) \\ 'University of Niš, Faculty of philosophy, Serbia \\ e-mail: jelena.osmanovic.zajic@filfak.ni.ac.rs; anastasija.mamutovic@filfak.ni.ac.rs; jelena.maksimovic@filfak.ni.ac.rs
}

\begin{abstract}
The challenges of contemporary education and teaching profession have resulted in an increased demand for the appropriate professional advancement and practice-based research. The action research is an approach that encourages teachers to manage and control their own work. This research was conducted with the purpose of being primarily beneficial for primary and secondary school teachers. The empirical research presented in this paper was based on the factor analysis, by which the research factors were extracted, as well as on the examination of the teachers' attitudes towards methodological education, cognition and metacognition in teaching, reflexive practice, science education and lifelong learning in the context of the action research. The method used was descriptive together with the scaling technique and the five-level Likert scale (AISE) consisting of 29 items. The research was realized in 2020, and then retested in 2021. The number of 1021 teachers from the Republic of Serbia participated in this research. The research results showed statistically significant differences in the respondents' responses related to the independent research variables: education cycle, teaching experience and the number of professional development seminars attended. The significance of action researches is reflected in the fact that the problems are resolved by the teachers themselves, not the scholars or academics who are not directly involved in teaching. Therefore, this research contributes to a greater motivation and support of teachers to raise their classroom activities and accomplishments to the level of a scientific research.
\end{abstract}

Keywords: action research, reflexive practice, science education, lifelong learning, empirical research.

\section{Introduction}

Action researches, aimed at the improvement of the education practice, are based on solving complex problems in practice, a cooperation of all research participants, a contribution of the research results to both theory and practice, a clear projection of reflexive processes, participants' attitudes characterized by criticism and self-criticism, as well as an original and genuine accomplishment typical of all phases of the research process. Thus, they involve both action (change and improvement) and research (recognition of these actions, knowledge structure and change) and are connected to the problems arising from practice. They stimulate innovative solutions, encourage cooperation and team work, and are inspired by a teacher's intention of improving their own practice in their teaching a particular group of schoolchildren.

Action research presupposes the research of a problem in a systematic way through defining certain key questions, planning and projecting the research, collection, processing and analysis of the data, interpreting the data and drawing the conclusions that will provide answers to the key questions. The primary value of the action research methodology is that it represents a catalyst of change. It is accomplished by comparing various points of view, exchanging ideas, analyzing the problem and finding potential solutions (Capone et al., 2016). Cognition and metacognition are significant aspects of action research. Permanent research and a critical attitude of teachers regarding the current teaching practice improve both their skills and abilities and the education process. Moreover, teachers are stimulated to ask questions about knowledge, postulate theories and construct their own knowledge. Metacognition includes awareness of the cognitive processes and achievements. The primary goal of the teacher-researcher is creating knowledge applicable to teaching and learning which erases the gap between theory and action. Therefore, what is created in the classroom is the link between the theory of science and the theory of teaching. This is the reason why action research has a positive impact on teachers' efficiency and

${ }^{\bar{C}}$ Corresponding author: jelena.osmanovic.zajic@filfak.ni.ac.rs 
the increase of their metacognitive knowledge while teaching (Balashov, Pasicichnyk and Kalamazh, 2021; Kavousi, 2016). Science education requires a comprehensive, dynamic and long-term continuous professional development of teachers that ensures sustainable learning. This goal presupposes that teachers are supported in all phases of their teaching career, especially considering the implementation of the curricula changes or the improvement of their teaching methods and styles of teaching. As regards a wide range of possibilities offered to teachers with the purpose of their professional development, action research is viewed as either a practice-oriented research of teachers' work and teaching in the classroom or a development of a new education strategy oriented to the deficiencies or personal interests of teachers and students (Eilks, 2018; Eilks, Naaman and Rauch, 2012). Whichever the case, action research is aimed at the improvement and change of the classroom practice and providing the necessary support to teachers needed for their continuous professional development. Action research is a powerful means that teachers are offered to improve their professional skills and leadership qualities. Action research is also acceptable because it encourages teachers to take their own initiative when it comes to the improvement of their teaching in case of encountering certain problems related to teaching and learning. This enables them to explore and test the teaching strategies and thus enhance their professional knowledge (Hairon, 2017). Teachers accept their professional development due to their own conviction that they will consequently enlarge their knowledge and skills, gain specific, particular and practical ideas which will all contribute to their personal advancement and increase their efficiency in teaching (Šteh, Kalin and Mažgon, 2021; Glanz, 2016; Hairon, 2017). Reflexion is essential to innovative teaching processes, which is therefore the area in which action research proves its relevance. The teachers who reflexively consider the improvement of their teaching methods and record their ideas with the purpose of understanding both the whole situation and their own selves are actually action researchers. They should be directed properly in relation to their professional development so that they are encouraged and stimulated to individually create their own teaching and learning strategies (Feldman and Capobianco, 2000; Fulmer, Chu and Martin, 2018; Goodnough, 2003).

All this emphasizes the fact that school teachers, representing a link between theory and practice in contemporary education, are most able to assess their own teaching, critically review their shortcomings, and accordingly improve their work by their own active engagement. Teachers are supposed to be experts in one or more school subjects (part of their academic education), autonomous professionals who constantly improve their knowledge, including their motivation to learn, be creative, cooperate, understand the education context, integrate the principles of lifelong learning into the processes of teaching and learning, explore and improve their own teaching practice. Action researches stimulate teachers' emancipation, i.e. their awareness of the necessity of lifelong learning. It is through action research that teachers realize in which areas they are efficient and in which ones they have to develop some additional competences.

Research practice and knowledge of methodology assume not only theoretical methodological knowledge but also practical knowledge necessary for the selection and application of the appropriate methodological procedures in researches and discussion of results (Tindowen, Guzman and Macanang, 2019). Various flaws encountered during the process of improving education result from teachers' insufficient knowledge of methodology. This may be resolved by devising curricula with reference to the competences that teachers have to learn and acquire. This mission could be based on the assumption that the concept of education and research has to be transformed into the concept of education through research. It is a well-known fact that not all teachers possess methodological competences, which means that they should be the focus of future education of teachers.

The vision of lifelong learning and continuous professional development demands that teachers consider issues critically, develop the ability for reflexion and evaluation, provide conditions for the academic advancement of every single student, stimulate and improve their own teaching methods. All this makes teaching more professional, whereas teachers are appointed new role, that of a researcher. Action research enables teachers to solve certain noted problems and improve their own practice in accordance with the autonomously set goals. The central part of action research is occupied by action, while the collected data are used as the feedback on the basis of which planned activities may be adapted and altered. This makes the whole research process flexible and creative in response to the needs of the participants in the research.

According to the aforementioned, the action research has a positive impact on teachers' work: it increases teachers' self-confidence, improves relationships with colleagues, invokes a better understanding of research processes, creates better teaching practice and motivates experimentation. Action research is an approach that encourages teachers to pursue academic advancement and thus control their own work. Action research is able to mitigate the gap between theory and practice (Bolton, 2010; Burnaford, 2011; Burns, 2010; Farel, 2004; Jay and Johson, 2002). The stimulation of teachers to carry out action research 
would enable the following: permanent professional improvement of teachers, implementation of changes in schools, professionalization of teaching, connection of theory and practice.

In order to be a successful scholar and researcher in the field of education, the teacherresearcher should possess certain theoretical, pedagogical and methodological skills, appreciate strict methodological procedures, obtain adequate research education and be creative. Education in the field of methodology is equally important for pedagogical practice and pedagogical theory, so the cooperation between a theoretician and a practitioner is a prerequisite for any crucial changes in education. This can be accomplished by action researches.

\section{Materials and Methods}

Every teacher that analyzes and evaluates their own practice is actually an action researcher. Therefore, the empirical research conducted examines the teachers' reflexion on the action research going beyond the teacher research. The goal of this research is to examine whether teachers reflect upon the feedback information related to their teaching and whether they use it to improve their teaching methods and their competencies.

The research tasks studied the following: self-evaluation of the teachers' methodological competences for carrying out action researches, cognition and metacognition in teaching as a very significant element of action researches, reflexive thinking applied in practical work, teachers' contribution to their own academic advancement and teachers' general attitudes towards lifelong learning and openness to innovations in teaching. The main hypothesis was the assumption that teachers knew the role of action research in teacher's education and that there would be a statistically significant difference in the respondents' replies regarding the sociodemographic characteristics of the research sample, i.e. the independent research variables, education cycle, teaching experience and the number of professional development seminars attended.

\section{Methods, Instruments and Statistical Procedures}

The research methods were selected in accordance with the research subject matter, goal, tasks and set hypothesis. The theoretical framework was based on the method of theoretical analysis together with the perception of various methodological approaches to the issue of the role of action research teachers in teachers' education. The method used was descriptive, which was also in accordance with the postulated research problem and it comprised the empirical and analytical parts of the research. The data concerning the teachers' attitudes towards the action research in relation to the teacher research were collected using the five-level (1-strongly disagree, 5-strongly agree) Likert scale containing 29 items, which was accepted as reliable and comprising all the metric characteristics (Cronbach's alpha test $=.76$ ).

\section{Sample}

The research sample was based on the following independent variables: education cycle - teachers teaching lower and higher grades in primary schools and secondary schools, teaching experience, the number of professional development seminars attended. The research was conducted on the territory of the Republic of Serbia during 2019/20 school year, and then retested in 2021. The teachers who participated in the research were selected on the basis of the simple random sample method, so that a total of 1021 teachers participated in the research. The participants were given the opportunity to fill the questionnaires at schools or electronically. Thus, every participant had an equal chance of being involved in the research.

Table 1.

Structure of the respondents by education cycle

\begin{tabular}{lcc}
\hline \multicolumn{1}{c}{ School } & $\mathrm{f}$ & $\%$ \\
\hline Elementary school & 693 & 67.2 \\
Secondary school & 328 & 32.8 \\
Total & 1021 & \\
\hline
\end{tabular}

Table 1 shows the structure of the respondents by the education cycle. 693 elementary school teachers and 328 secondary school teachers participated in the research, totaling a number of 1021 $(100 \%$ of the sample). 
Table 2.

Structure of the respondents by teaching experience

\begin{tabular}{lcc}
\hline \multicolumn{1}{c}{ Teaching experience } & $f$ & $\%$ \\
\hline $0-10$ & 418 & 40.5 \\
$11-20$ & 483 & 46.8 \\
Over 20 & 120 & 12.6 \\
Total & 1021 & \\
\hline
\end{tabular}

Table 2 shows the structure of the respondents by the second independent variable, teaching experience. The majority of the respondents had 0 to 20 years of teaching experience $(0-10, N=28 ; 11-20$, $\mathrm{N}=483$ ), while 120 of the respondents had over 20 years of teaching experience.

Table 3.

Structure of the respondents by the number of professional development seminars attended

\begin{tabular}{ccc}
\hline Number of seminars & $f$ & $\%$ \\
\hline 0 & 188 & 18.2 \\
1 & 122 & 11.8 \\
2 & 64 & 6.2 \\
3 & 120 & 11.6 \\
4 & 119 & 11.5 \\
5 & 78 & 7.6 \\
7 & 88 & 8.5 \\
8 & 78 & 7.6 \\
9 & 41 & 4.0 \\
10 & 76 & 7.4 \\
11 & 40 & 3.9 \\
12 & 7 & .7 \\
Total & 1021 & \\
\hline
\end{tabular}

Table 3 shows that the number of professional development seminars attended ranges from 0 to 12 , which means that certain respondents had never had the opportunity of attending a professional seminar while some had attended them several times (See the columns with frequencies and percentages).

\section{Data Analysis}

The data obtained using the factor analysis were analyzed by means of the descriptive statistics (arithmetic mean M and standard deviation SD). The procedure of multivariate statistics was first used in the research. Five research factors were extracted using the procedure of the factor analysis with a Varimax rotation: Teachers' methodological education, Cognition and Metacognition, Reflexive practice, Science Education and Lifelong learning. The items were appropriately grouped within the framework of each of the research factors and the statistical analysis was performed on the basis of the data factorization and in accordance with the postulated independent research variables. The research also used the parametric statistics of the t test and ANOVA test in order to examine the statistically significant differences in the teachers' responses concerning their teaching experience, education cycle and the number of professional development seminars attended, as well as the Bonfferoni post hoc procedure for those factors for which a statistically significant $p<.05$ was observed. 


\section{Results}

The major research components used for a further data analysis were extracted by means of the factor analysis.

Table 4.

Factor analysis of the data

\begin{tabular}{ccccccc}
\hline Component & \multicolumn{3}{c}{ Initial Eigenvalues } & \multicolumn{3}{c}{ Extraction Sums of Squared Loadings } \\
\hline & Total & $\begin{array}{c}\% \\
\text { of Variance }\end{array}$ & $\begin{array}{c}\text { Cumulative } \\
\%\end{array}$ & Total & $\begin{array}{c}\% \text { of } \\
\text { Variance }\end{array}$ & $\begin{array}{c}\text { Cumulative } \\
\%\end{array}$ \\
\hline 1 & 10.617 & 36.611 & 36.611 & 10.617 & 36.611 & 36.611 \\
2 & 2.471 & 8.522 & 45.133 & 2.471 & 8.522 & 45.133 \\
3 & 1.980 & 6.829 & 51.962 & 1.980 & 6.829 & 51.962 \\
4 & 1.559 & 5.377 & 57.339 & 1.559 & 5.377 & 57.339 \\
5 & 1.476 & 5.090 & 62.428 & 1.476 & 5.090 & 62.428 \\
\hline 6 & 1.240 & 4.275 & 66.704 & 1.240 & 4.275 & 66.704 \\
7 & 1.152 & 3.973 & 70.677 & 1.152 & 3.973 & 70.677 \\
8 & 1.140 & 3.931 & 74.608 & 1.140 & 3.931 & 74.608 \\
\hline
\end{tabular}

Extraction Method: Principal Component Analysis.

Eight factors were extracted by the data factor analysis. Since 5 factors satisfied all the criteria of the factor correlation with over $50 \%$ of the cumulative variance, i.e. $62.43 \%$, all 5 factors were retained for analysis whereas the items were grouped within the items using a Varimax rotation.

Table 5.

Rotated Component Matrix

\begin{tabular}{|c|c|c|c|c|c|}
\hline & \multicolumn{5}{|c|}{ Component } \\
\hline & 1 & 2 & 3 & 4 & 5 \\
\hline $\mathrm{p} 9$ & 851 &, 074 & 297 &, 089 &, 029 \\
\hline $\mathrm{p} 11$ & 841 &, 091 &, 076 & ,173 & ,214 \\
\hline p10 & 834 & ,112 &, 112 & 140 & 112 \\
\hline p12 &, 738 & 156 &, 318 &, 035 &, 350 \\
\hline p3 &, 685 & 235 & 272 &, 113 & 102 \\
\hline p7 &, 670 & ,415 & 180 &, 145 &,- 016 \\
\hline $\mathrm{p} 1$ & 659 & ;261 &, 096 & 138 & ,138 \\
\hline p6 & 436 & ,236 &, 350 &, 223 &,- 100 \\
\hline p21 &, 095 & 811 & -007 & 130 &, 002 \\
\hline p17 &, 175 &, 782 & 205 &, 002 & ,102 \\
\hline p16 &, 292 & 750 & 184 & , 101 & ,125 \\
\hline p20 & 149 &, 697 & -053 &, 354 &, 082 \\
\hline p18 &, 124 &, 623 & 204 & 320 & 225 \\
\hline p22 &, 087 & 569 & 336 & 141 &, 038 \\
\hline p15 &, 256 & 557 & ,102 & 327 &, 349 \\
\hline p29 & ,182 & 242 & 822 &, 119 &, 228 \\
\hline p28 & 288 & ,121 &, 777 & ,158 & ,245 \\
\hline p27 &, 304 & 115 &, 735 &, 340 &,- 016 \\
\hline p26 &, 300 & 123 &, 710 & 268 &,- 040 \\
\hline p2 & ,124 & ,123 & 289 &, 706 &, 119 \\
\hline p24 & ,287 & 174 & 299 & 700 &, 081 \\
\hline p23 &, 084 & 299 &, 212 &, 689 &, 062 \\
\hline $\mathrm{p} 4$ & ,156 & 255 &,- 030 &, 628 &,- 012 \\
\hline p25 & ,196 & 162 &, 368 &, 550 &, 117 \\
\hline p13 &, 266 &, 069 & 154 &, 078 & 885 \\
\hline p14 & 142 & 279 & 087 & 103 & 820 \\
\hline
\end{tabular}

Extraction Method: Principal Component Analysis.

Rotation Method: Varimax with Kaiser Normalization. 
Factor analysis was used in order to group the items into the factors. The advantage of factor analysis is reflected in the fact that it solved the issue of multi-correlativity. Therefore, the results of factor analysis were beneficial for further statistical analysis.

Scree Plot

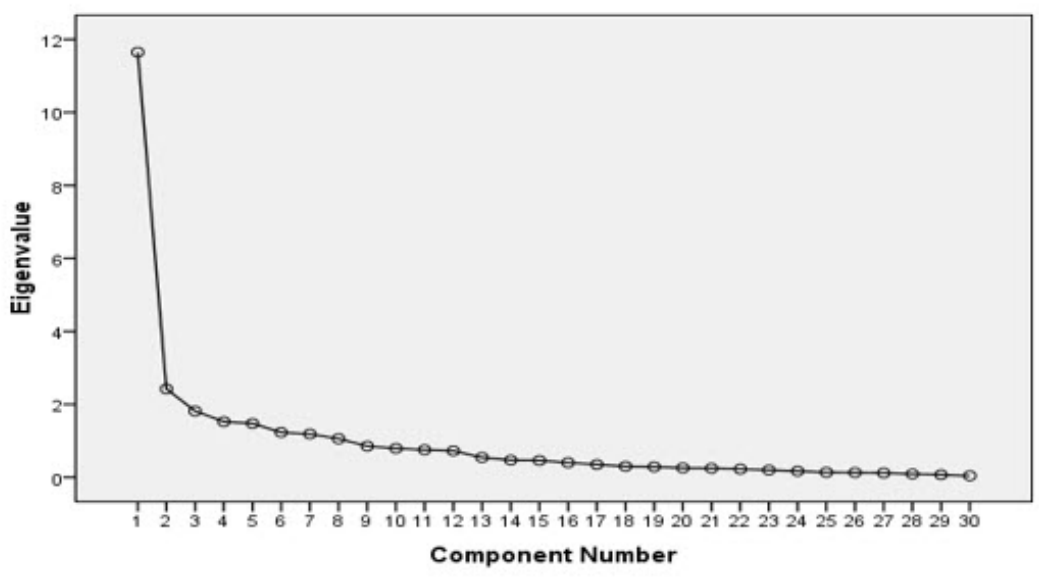

Figure 1. Scree Plot

The scree plot confirms the fact that the teachers' attitudes and action research in the scientific context can be analyzed by 5 major factors that explain over $50 \%$ of the total cumulative variance. All five factors are relevant; however, the first factor is at the highest level of significance.

The first factor was named Methodological component of action researches and it comprised the following items: 1. Knowledge of methodology is essential to the improvement of education and teaching; 2. The study of teaching and education practice requires methodological knowledge, such as construction and the use of instruments; 3 . Teachers are expected to know methodology in order to carry out the action research successfully; 4. Professional development is preconditioned by methodological literacy and culture; 5 . Attending seminars on the Methodology of pedagogical research should be compulsory for teachers.

Table 6.

Descriptive statistics of the factor Methodological component of action researches

\begin{tabular}{cccccc}
\hline & $\mathrm{N}$ & Min & Max & M & SD \\
\hline p1 & 1021 & 1.00 & 5.00 & 3.6200 & .92278 \\
p2 & 1021 & 1.00 & 5.00 & 4.1391 & .74245 \\
P3 & 1021 & 1.00 & 5.00 & 3.6983 & 1.01319 \\
p4 & 1021 & 1.00 & 5.00 & 4.1518 & .75891 \\
p5 & 1021 & 2.00 & 4.00 & 4.2449 & 3.63760 \\
\hline
\end{tabular}

The items and the sums of the arithmetic means of the first factor were grouped into one variable, Methodological component of action researches, which was used for further analysis. This factor was highly valued by the teachers (Table 6).

The second factor was named Cognition and Metacognition and it comprised the following factors: 1. Being a teacher, I reflect on my own philosophy of teaching; 2 . I ponder the significance or meaning of my teaching profession; 3. I endeavor to realize which aspect of teaching makes me content; 4 . I contemplate both good and bad sides of my teaching; 5 . I consider inconsistencies and contradictions occurring in practice. 
Table 7.

Descriptive statistics of the factor Cognition and Metacognition

\begin{tabular}{cccccc}
\hline & $\mathrm{N}$ & Min & Max & M & SD \\
\hline 1 & 1021 & 1.00 & 5.00 & 3.7806 & 1.12845 \\
2 & 1021 & 1.00 & 5.00 & 3.7777 & .97645 \\
3 & 1021 & 1.00 & 4.00 & 4.7209 & 5.77261 \\
4 & 1021 & 1.00 & 5.00 & 3.5357 & 1.17904 \\
5 & 1021 & 1.00 & 5.00 & 3.6964 & 1.23029 \\
\hline
\end{tabular}

The items and the sums of the arithmetic means of the second factor were grouped into one variable, Methodological component of action researches, which was used for further statistical analysis. According to the respondents' replies, the factor was separated as ranging from indifference to agreement on the assessment scale (Table 7).

The third factor was named The teacher as a reflexive practitioner and action researcher and was comprised of the following items: 1 . I have a file where I keep all my school reports; 2 . I exchange teaching experience with my colleagues and seek advice and feedback information; 3. I record accomplishments/ failures related to each taught lesson or unit; 4 . I discuss practical/theoretical issues with my colleagues; 5. I attend and observe my colleagues' classes with the purpose of learning more about their efficient practice; 6 . I prompt my superiors to observe my classes and comment on my output and efficiency.

Table 8.

Descriptive statistics of the factor The teacher as a reflexive practitioner and action researcher

\begin{tabular}{cccccc}
\hline & $\mathrm{N}$ & Min & Max & M & SD \\
\hline 1 & 1021 & 1.00 & 5.00 & 3.7385 & 1.16618 \\
2 & 1021 & 1.00 & 5.00 & 3.9109 & 1.07962 \\
3 & 1021 & 2.00 & 5.00 & 4.4319 & .82991 \\
4 & 1021 & 2.00 & 5.00 & 4.5201 & .69652 \\
5 & 1021 & 3.00 & 5.00 & 4.6004 & .58155 \\
6 & 1021 & 2.00 & 5.00 & 4.4074 & .71298 \\
\hline
\end{tabular}

The items and the sums of the arithmetic means of the third factor were grouped into one variable, the teacher as a reflexive practitioner and action researcher, which was used for further statistical analysis. The majority of the teachers highly valued this factor (Table 8).

The fourth factor was named Science Education and it comprised the following items: 1. I read books/papers on efficient teaching; 2 . I participate in workshops/conferences on the issues related to teaching/learning; 3. I plan to write the papers based on my classroom experiences; 4 . I refer to the papers or browse the Internet in order to learn about the latest accomplishments in my profession; 5. I conduct minor researches during my classes; 6 . I consider teaching as a potential matter for a research and I ponder methods to use in that research.

Table 9.

Descriptive statistics of the factor Science Education

\begin{tabular}{cccccc}
\hline & $\mathrm{N}$ & Min & Max & M & SD \\
\hline & & & & & \\
1 & 1021 & 2.00 & 5.00 & 4.2693 & .73760 \\
2 & 1021 & 3.00 & 5.00 & 4.2331 & .66460 \\
3 & 1021 & 3.00 & 4.00 & 4.4643 & 3.89443 \\
4 & 1021 & 3.00 & 5.00 & 4.2243 & .73674 \\
5 & 1021 & 3.00 & 5.00 & 4.2458 & .71077 \\
6 & 1021 & 2.00 & 5.00 & 4.3193 & .72349 \\
\hline
\end{tabular}

The items and the sums of the arithmetic means of the fourth factor were grouped into one variable, Science Education, which was used for further statistical analysis. This factor and all of its items were highly valued on the Likert scale by the teachers (Table 9).

The fifth factor was named Lifelong learning and it comprised the following items: 1. I constantly 
aspire to something new; 2 . I continually develop and improve myself; I want to understand the traits of methodology to be able to do a research; 3 . I want to learn how to write reports on the conducted action research; 4 . I never miss the seminars that can help me improve the quality of my teaching; 5 . Lifelong learning is the goal of each profession.

Table 10.

Descriptive statistics of the factor Lifelong learning

\begin{tabular}{cccccc}
\hline & $\mathrm{N}$ & Min & Max & M & SD \\
\hline p24 & 1021 & 2.00 & 5.00 & 4.2096 & .74698 \\
p25 & 1021 & 2.00 & 5.00 & 4.3849 & .76551 \\
p26 & 1021 & 1.00 & 5.00 & 4.4358 & .92410 \\
p27 & 1021 & 1.00 & 5.00 & 4.4750 & .85784 \\
p28 & 1021 & 2.00 & 5.00 & 4.6161 & .68991 \\
p29 & 1021 & 2.00 & 5.00 & 4.6317 & .68709 \\
\hline
\end{tabular}

The items and the sums of the arithmetic means of the five factor were grouped into one variable, Lifelong learning, which was used for further statistical analysis. The items of the factor Lifelong learning, which was estimated as extremely important, are shown in Table 10.

Table 11.

Methodological component of action researches considering the education cycle

\begin{tabular}{llcccccc}
\hline & Education cycle & $\mathrm{N}$ & $(\mathrm{M})$ & $(\mathrm{SD})$ & $\mathrm{t}$ test & $\mathrm{df}$ & $\mathrm{p}$ \\
\hline $\begin{array}{l}\text { Methodological } \\
\text { component }\end{array}$ & Primary school & 693 & 19.93 & 2.64 & & & \\
& Secondary school & 328 & 19.68 & 7.32 & & & \\
\hline
\end{tabular}

Contemporary system of education emphasizes the significance of teachers' analytical and research work, as well as their being methodologically trained to conduct reflexive practice. Teachers, on the other hand, are becoming more aware of the fact that methodological knowledge and competences are essential for their independent study of teaching practice. Teachers also value the need to improve their methodological knowledge in order to conduct action researches. Using the t test, the presented research examined whether the teachers' attitudes towards the methodological component of action researches differed considering the variable education cycle. The obtained results showed that regardless of the cycle of education, teachers who taught in both primary and secondary schools valued highly the necessity of the methodological knowledge. Their responses demonstrated no statistically significant difference, i.e. the number of homogenous responses predominated, $p>.05$.

Table 12.

Methodological component of action researches considering teaching experience

\begin{tabular}{cccccc}
\hline $\begin{array}{c}\text { Methodological } \\
\text { component }\end{array}$ & $\begin{array}{c}\text { Sum of } \\
\text { Squares }\end{array}$ & df & Mean Square & $\mathrm{F}$ & $\mathrm{p}$ \\
\hline Between Groups & 23.090 & 2 & 11.54 & .52 & .59 \\
Within Groups & 22382.166 & 1018 & 21.98 & & \\
Total & 22405.256 & 1020 & & & \\
\hline
\end{tabular}

The issue of the necessity of methodological education for conducting action researches was tested considering the variable teaching experience. All of the teachers who participated in the research, regardless of their teaching experience, agreed that the methodological component was essential for conducting researches. Regardless of the years of teaching experience, both less experienced and more experienced teachers valued highly the need to gain methodological knowledge and competences, so that their responses showed no statistically significant difference, $p>.05$. 
Table 13.

Methodological component of action researches considering the number of professional development seminars attended

\begin{tabular}{ccccc}
\hline & $\begin{array}{c}\text { (J) Number of } \\
\text { seminars attended }\end{array}$ & $\begin{array}{c}\text { Mean Difference } \\
(I-J)\end{array}$ & Std. Error & $p$ \\
\hline 1 & -1.02511 & .46947 & 1.000 \\
& 2 & -1.83710 & .58440 & .113 \\
& 3 & -1.46418 & .47183 & .130 \\
(I) Methodological & 4 & $-4.75648\left(^{*}\right)$ & .47304 & .0001 \\
component & 5 & $-9.21931\left(^{*}\right)$ & .54387 & .0001 \\
& 7 & $-2.04449\left(^{*}\right)$ & .52157 & .006 \\
& 8 & $-1.88598\left(^{*}\right)$ & .54387 & .036 \\
& 9 & $-2.65646\left({ }^{*}\right)$ & .69603 & .009 \\
& 10 & $-3.36506\left(^{*}\right)$ & .54891 & .0001 \\
& 11 & $-4.18085\left(^{*}\right)$ & .70314 & .0001 \\
& 12 & -3.68085 & 1.55443 & 1.000 \\
\hline
\end{tabular}

* The mean difference is significant at the .05 level.

The differences in the respondents' responses were obtained using the multiple comparison of the teachers' answers to the question of the significance and necessity of methodological knowledge for conducting action researches. The comparison of the teachers' responses showed that the teachers who had attended 4 or more professional development seminars valued more the necessity of methodological education for conducting action researches than those who had rarely attended such seminars. The difference in the responses of these two groups of teachers is statistically significant, $p<.05$.

The data shown in Tables 11, 12 and 13 partially confirmed the hypothesis that there are statistically significant differences in the respondents' responses considering the independent variables education cycle, teaching experience and the number of professional development seminars attended. The differences in the teachers' responses are evident considering only one variable - the number of seminars attended, $p<.05$, but not regarding the other two variables, education cycle and teaching experience, $p>0.05$.

Table 14.

Cognition and metacognition considering education cycle

\begin{tabular}{lccccccc}
\hline & $\begin{array}{c}\text { Education } \\
\text { cycle }\end{array}$ & $\mathrm{N}$ & (M) & (SD) & t test & df & $\mathrm{p}$ \\
\hline Cognition and & $\begin{array}{c}\text { Primary } \\
\text { school }\end{array}$ & 693 & 19.99 & 7.48 & 3.32 & 1019 & .001 \\
metacognition & $\begin{array}{c}\text { Secondary } \\
\text { school }\end{array}$ & 328 & 18.48 & 4.92 & & & \\
\hline
\end{tabular}

Metacognition is a manner of predicting, understanding, controlling and assessing cognition. The teachers were questioned about their own teaching philosophy, the feeling of satisfaction with their own profession, their perception of good and bad sides of teaching, their reflections on failures, inconsistencies and contradictions of teaching practice.

Cognition and metacognition are present in the work of teachers-action researchers; however, the respondents' responses are characterized by statistically significant differences. This research proved that cognition and metacognition were more present in the work of primary school teachers $(M=19.99)$ than in the work of secondary school teachers $(M=18.49)$. The difference is statistically significant, $p<$ $.05 ; p=.001$. 
Table 15.

Cognition and metacognition in teaching considering teaching experience

\begin{tabular}{ccccc}
\hline $\begin{array}{c}\text { (I) Yrs of teaching } \\
\text { experience }\end{array}$ & $\begin{array}{c}(\mathrm{J}) \text { Yrs of teaching } \\
\text { experience }\end{array}$ & Mean Difference & Std. Error & $\mathrm{p}$ \\
\hline 0-10 & $11-20$ & $(\mathrm{I}-\mathrm{J})$ & & \\
& over 20 & $2.67170\left(^{*}\right)$ & .45009 & .001 \\
$0-10$ & $\mathrm{~N}$ & $\mathrm{M}$ & .69777 & .001 \\
$11-20$ & 418 & 20.6220 & $\mathrm{SD}$ & $\mathrm{N}$ \\
Over 20 & 483 & 18.9503 & 8.52845 & $0-10$ \\
Total & 120 & 17.9000 & 4.81500 & $11-20$ \\
\hline
\end{tabular}

Table 15 proves that the component cognition and metacognition predominated among the teachers with the fewest years of teaching experience (0-10). The differences in the respondents' responses were obtained using the multiple comparison of the teachers' answers about cognition and metacognition in teaching. The comparison of the teachers' answers showed that the teachers with $0-10$ years of teaching experience valued more the factor of cognition and metacognition than those with 11-20 and more than 20 years of teaching experience. The differences were statistically significant, $p<.05$.

Table 16.

Cognition and metacognition in teaching considering the number of seminars attended

\begin{tabular}{lcccc}
\hline & $\begin{array}{c}\text { (J) Number of } \\
\text { seminars } \\
\text { attended }\end{array}$ & Mean Difference (I-J) & Std. Error & $p$ \\
\hline 1 & -1.32630 & .68633 & 1.000 \\
& 2 & -.20745 & .85436 & 1.000 \\
Cognition and & 3 & $-2.42411\left(^{*}\right)$ & .68979 & .0301 \\
metacognition & 4 & $-4.10451\left(^{*}\right)$ & .69155 & .0001 \\
& 5 & $-6.14975\left(^{*}\right)$ & .79510 & .0001 \\
& 7 & -2.13926 & .76251 & .0301 \\
& 8 & -12.56001 & .79510 & .3201 \\
& 9 & $2.98158\left(^{*}\right)$ & 1.01755 & .0301 \\
& 10 & $-5.20745\left(^{*}\right)$ & .80246 & .0001 \\
& 11 & $-3.95745\left(^{*}\right)$ & 1.02794 & .0081 \\
& 12 & -.45745 & 2.27247 & 1.000 \\
\hline
\end{tabular}

* The mean difference is significant at the .05 level.

The differences in the respondents' responses were obtained using the multiple comparison of the teachers' answers regarding cognition and metacognition in teaching. The comparison of the teachers' answers proved that the teachers who had attended 3 or more (11 at most) professional development seminars valued more the factor of cognition and metacognition than those who had attended only one or possibly two professional development seminars. The difference in the responses of the teachers who had been improving themselves professionally and those who had done it "rarely" is statistically significant, $p<.05$.

The data shown in Tables 14, 15 and 16 prove the existence of the statistically significant differences in the respondents' responses considering the independent variables education cycle, teaching experience and the number of attended seminars, which confirms the hypothesis that there are statistically significant differences considering the independent variables of the research. The differences were actually evident in the teachers' responses regarding the independent variables, $p<.05$. 
Table 17.

Reflexive practice and teachers' action researches considering education cycle

\begin{tabular}{cccccccc}
\hline & $\begin{array}{c}\text { Education } \\
\text { cycle }\end{array}$ & $\mathrm{N}$ & $(\mathrm{M})$ & $(\mathrm{SD})$ & $\mathrm{t}$ test & $\mathrm{df}$ & $\mathrm{p}$ \\
\hline $\begin{array}{c}\text { Reflexive practice and } \\
\text { action researches }\end{array}$ & $\begin{array}{c}\text { Primary } \\
\text { school }\end{array}$ & 693 & 25.9206 & 3.51846 & & & \\
$\begin{array}{c}\text { Secondary } \\
\text { school }\end{array}$ & 328 & 24.9512 & 4.31171 & 3.81 & 1019 & .001 \\
\hline
\end{tabular}

Reflexive practice has become an issue that is commonly discussed in the context of education and teaching. Reflexivity and reflexive practice are actually very important elements of efficient teaching and teachers' professional development. Teachers who are reflexive practitioners, i.e. action researchers, have to keep records of their teaching, exchange teaching experiences with their colleagues regarding their own accomplishments in class and analyze practical problems together. The obtained results showed that the primary school teachers valued more the factor of reflexivity in teaching and the significance of action researches $(M=25.92)$ than the secondary school teachers $(M=24.95)$. The difference in their responses was statistically significant, $p<.05 ; p=.05$.

Table 18.

Teachers' reflexive practice and action researches considering teaching experience

\begin{tabular}{cccccc}
\hline $\begin{array}{c}\text { Reflexive practice and } \\
\text { action researches }\end{array}$ & $\begin{array}{c}\text { Sum of } \\
\text { Squares }\end{array}$ & $\mathrm{df}$ & Mean Square & $\mathrm{F}$ & $\mathrm{p}$ \\
\hline $\begin{array}{c}\text { Between Groups } \\
\text { Within Groups }\end{array}$ & $\begin{array}{c}148.109 \\
\text { Total }\end{array}$ & 2 & 10.054 & & \\
& 14855.073 & 1018 & 14.573 & .690 & .502 \\
$0-10$ & $\mathrm{~N}$ & $\mathrm{M}$ & $\mathrm{SD}$ & & $\mathrm{N}$ \\
$11-20$ & 418 & 25.5024 & 3.16171 & $0-10$ & 418 \\
Over 20 & 483 & 25.6128 & 4.18419 & $11-20$ & 483 \\
Total & 120 & 25.9667 & 4.32684 & Over 20 & 120 \\
& 1021 & 25.6092 & 3.81625 & Total & 1021 \\
\hline
\end{tabular}

The teachers were questioned about reflexive practice and action researches considering the variable teaching experience. The obtained results showed that regardless of their teaching experience, both less experienced and more experienced teachers valued highly the necessity of reflexive practice for a successful conduct of action researches. Their responses did not demonstrate any statistically significant difference, i.e. the responses are homogenous, $p>.05$.

Table 19.

Teachers' reflexive practice and action researches considering the number of seminars attended

\begin{tabular}{ccccc}
\hline & $\begin{array}{c}\text { (J) Number of seminars } \\
\text { attended }\end{array}$ & Mean Difference (I-J) & Std. Error & $p$ \\
\hline 1 & -1.03113 & .41567 & .876 \\
& 2 & -1.51064 & .51744 & .237 \\
& 3 & $-2.24397\left(^{*}\right)$ & .41777 & .0001 \\
(I) Teachers' & 4 & $-3.54635\left(^{*}\right)$ & .41884 & .0001 \\
reflexive & 5 & $-3.77346\left(^{*}\right)$ & .48155 & .0001 \\
practice & 7 & -1.16973 & .46181 & .757 \\
& 8 & -.97859 & .48155 & 1.000 \\
& 9 & -1.62649 & .61628 & .557 \\
& 10 & $-3.43169\left(^{*}\right)$ & .48601 & .0001 \\
& 11 & $-3.76064\left(^{*}\right)$ & .62257 & .0001 \\
& 12 & $-6.26064\left(^{*}\right)$ & 1.37632 & .0001 \\
\hline
\end{tabular}

The mean difference is significant at the .05 level. 
The differences in the respondents' responses were obtained using the multiple comparison of the teachers' answers regarding reflexive practice. The comparison of the teachers' answers within groups showed that the teachers who had attended 3 or more (with the exceptions in some cases) professional development seminars valued more the factor of the importance of reflexive practice for conducting action researches than those who had done that rarely. In the majority of cases, the difference in the teachers' responses considering the number of professional development seminars attended is statistically significant, $p<.05$.

The data shown in the Tables 17, 18 and 19 partially confirm the hypothesis that there is statistically significant difference in the respondents' responses considering the independent variables education cycle, teaching experience and the number of attended seminars. The differences in the teachers' responses were evident in relation to the variable's education cycle and the number of attended seminars, $p<.05$, but not in relation to teaching experience, $p>.05$.

Table 20.

Science education considering education cycle

\begin{tabular}{llcccccc}
\hline & Education cycle & $\mathrm{N}$ & (M) & (SD) & t test & df & $\mathrm{p}$ \\
\hline Science education & Primary school & 693 & 30.41 & 5.86 & \multirow{2}{*}{2.18} & \multirow{2}{*}{1019} & .03 \\
& Secondary school & 328 & 29.63 & 3.99 & & & \\
\hline
\end{tabular}

Contemporary education system emphasizes the importance of teachers' analytical and research activities and their methodological education for reflexive practice and conduct of action researches. The goal of this research is to indicate that education of teachers and future teachers is important for enabling them to conduct their own researches, study reference materials, process and interpret the results obtained from their own practical work. For this purpose, the attitudes of teachers to the factor Science education were examined, i.e. the research explored whether the teachers attended workshops and scientific conferences on the issues of teaching and learning, whether they intended to write scientific and scholarly papers based on their classroom experience, whether they made use of additional reference materials and were informed about new accomplishments in their own profession and whether they conducted some minor action researches in their classes. The obtained results showed that the primary school teachers $(M=30.41)$ valued more the factor Science education than the secondary school teachers $(M=29.63)$. The difference in their attitudes was statistically significant, $p<.05 ; p=.03$.

Table 21.

Science education considering teaching experience

\begin{tabular}{cccccc}
\hline Science education & $\begin{array}{c}\text { Sum of } \\
\text { Squares }\end{array}$ & $\mathrm{df}$ & Mean Square & $\mathrm{F}$ & $\mathrm{p}$ \\
\hline Between Groups & 179.841 & 2 & 89.921 & & \\
Within Groups & 28951.843 & 1018 & 28.440 & 3.162 & .043 \\
Total & 29131.685 & 1020 & & & \\
& $\mathrm{~N}$ & $\mathrm{M}$ & $\mathrm{SD}$ & & $\mathrm{N}$ \\
$0-10$ & 418 & 29.9234 & 3.58305 & $0-10$ & 418 \\
$11-20$ & 483 & 30.5694 & 6.79126 & $11-20$ & 483 \\
Over 20 & 120 & 29.3667 & 3.39038 & Over 20 & 120 \\
Total & 1021 & 30.1636 & 5.34420 & Total & 1021 \\
\hline
\end{tabular}

The teachers were questioned about the factor Science education considering their teaching experience. The obtained results demonstrated that the teachers' responses differed regarding their teaching experience and that they valued highly the factor Science education. Therefore, their responses are statistically different, $p<.05$. 
Table 22.

Science education considering the number of attended seminars

\begin{tabular}{ccccc}
\hline & $\begin{array}{c}\text { (J) Number of seminars } \\
\text { attended }\end{array}$ & Mean Difference (I-J) & Std. Error & $p$ \\
\hline & 1 & .15094 & .56298 & 1.000 \\
& 2 & -2.32447 & .70082 & .062 \\
& 3 & $-3.24113\left(^{*}\right)$ & .56582 & .0001 \\
(I) Number of & 4 & $-7.30766\left(^{*}\right)$ & .56727 & .0001 \\
seminars & 5 & $-4.09370\left(^{*}\right)$ & .65221 & .0001 \\
attended & 7 & -2.07447 & .62547 & .062 \\
& 8 & $-3.14498\left(^{*}\right)$ & .65221 & .0001 \\
& 9 & -.88544 & .83468 & 1.000 \\
& 10 & -1.90342 & .65825 & .258 \\
& 11 & $-4.82447\left(^{*}\right)$ & .84320 & .0001 \\
& 12 & -4.32447 & 1.86407 & 1.000 \\
\hline
\end{tabular}

* The mean difference is significant at the .05 level

The differences in the respondents' responses were obtained using the multiple comparison of the teachers' answers to the question of Science education. The comparison of their answers within groups showed that the teachers who had attended 2 or more (which was the case with the majority of the teachers) professional development seminars valued more the factor Science education than those who had not attended them as often as it was necessary. The difference in the teachers' responses regarding the number of seminars attended was statistically significant, $p<.05$.

The data shown in the Tables 20, 21 and 22 confirm the hypothesis that there is statistically significant difference in the respondents' responses considering the independent variables education cycle, teaching experience and the number of attended seminars, $p<0.05$.

Table 23.

Teachers' lifelong learning considering education cycle

\begin{tabular}{cccccccc}
\hline & $\begin{array}{c}\text { Education } \\
\text { cycle }\end{array}$ & $\mathrm{N}$ & $(\mathrm{M})$ & (SD) & $\mathrm{t}$ test & $\mathrm{df}$ & $\mathrm{p}$ \\
\hline Lifelong & $\begin{array}{c}\text { Primary } \\
\text { school } \\
\text { learning }\end{array}$ & 693 & 35.74 & 3.78 & & & \\
$\begin{array}{c}\text { Secondary } \\
\text { school }\end{array}$ & 328 & 34.43 & 5.76 & 4.31 & 1019 & .001 \\
\hline
\end{tabular}

The knowledge of methodology is the basis of any research conducted in all sciences, so that the methodological competence of a pedagogue represents a fundamental condition for their professional development, innovative teaching and improvement of education. This research examined whether the teachers aspired to something new, whether they wanted to use their professional development to perceive how to explore their teaching practice by means of action researches and learn how to write reports on conducted action researches, whether their attitude to lifelong or permanent education was positive. The obtained results proved that the primary school teachers $(M=35.74)$ valued more lifelong learning in the context of action researches than the secondary school teachers $(M=34.43)$. The difference in their responses was statistically significant, $p<.05 ; p=.001$. 
Table 24.

Teachers' lifelong learning considering teaching experience

\begin{tabular}{lcccc}
\hline $\begin{array}{l}\text { (I) Yrs of teaching } \\
\text { experience }\end{array}$ & $\begin{array}{c}(\mathrm{J}) \text { Yrs of teaching } \\
\text { experience }\end{array}$ & $\begin{array}{c}\text { Mean Difference } \\
(\mathrm{I}-\mathrm{J})\end{array}$ & Std. Error & $\mathrm{p}$ \\
\hline $0-10$ & $11-20$ & $.99715\left(^{*}\right)$ & .30184 & .003 \\
& over 20 & $1.80957\left({ }^{*}\right)$ & .46794 & .0001 \\
$0-10$ & $\mathrm{~N}$ & $\mathrm{M}$ & $\mathrm{SD}$ & \\
$11-20$ & 418 & 36.0096 & 3.38000 & $0-10$ \\
Over 20 & 483 & 35.0124 & 4.88794 & $11-20$ \\
Total & 120 & 34.2000 & 6.15159 & Over 20 \\
\hline
\end{tabular}

* The mean difference is significant at the .05 level.

The differences in the respondents' responses were obtained using the multiple comparison of the teachers' answers to the question about lifelong learning. The comparison of their answers within groups showed that the teachers with $0-10$ years of teaching experience valued more the factor of lifelong learning than those with 11-20 and over 20 years of teaching experience. The differences in their responses were statistically significant, $p<.05$.

Table 25.

Teachers' lifelong learning considering the number of attended seminars

\begin{tabular}{ccccc}
\hline & $\begin{array}{c}\text { (J) Number of attended } \\
\text { seminars }\end{array}$ & $\begin{array}{c}\text { Mean Differ- } \\
\text { ence }(I-J)\end{array}$ & Std. Error & $p$ \\
\hline 1 & $-2.09583\left(^{*}\right)$ & .48710 & .001 \\
& 2 & -1.13630 & .60636 & 1.000 \\
& 3 & $-1.75922\left(^{*}\right)$ & .48956 & .023 \\
& 4 & $-5.30096\left(^{*}\right)$ & .49081 & .0001 \\
(I) lifelong learning & 5 & $-6.03614\left(^{*}\right)$ & .56431 & .0001 \\
& 7 & $-2.86074\left(^{*}\right)$ & .54117 & .0001 \\
& 8 & $-3.44640\left(^{*}\right)$ & .56431 & .0001 \\
& 9 & $-3.60963\left(^{*}\right)$ & .72218 & .0001 \\
& 10 & $-3.17413\left(^{*}\right)$ & .56953 & .0001 \\
& 11 & -2.29255 & .72955 & .114 \\
& 12 & -4.29255 & 1.61283 & .522 \\
\hline
\end{tabular}

* The mean difference is significant at the .05 level.

The differences in the respondents' responses were obtained using the multiple comparison of the teachers answers to the question about lifelong learning. The comparison of their answers within groups demonstrated that the teachers who had attended not fewer than one seminar and not more than 10 seminars had more positive attitudes to lifelong learning than those who did not exhibit any preferences regarding lifelong learning and improvement, $p<.05$.

The data shown in the Tables 23,24 and 25 confirm the hypothesis that there is statistically significant difference in the respondents' responses considering the independent variables education cycle, teaching eperience and the number of attended seminars. The differences in the respondents' answers were present regarding all the independent variables of the research and their responses are not homogenous, $p<.05$.

\section{Discussions}

The presented empirical research used the procedure of the factor analysis to extract 5 factors that were the basis for a further statistical processing, analysis and interpretation of the research results. The following are the research results and suggestions for the scientific community:

There is no statistically significant difference in the responses related to the factor Methodological 
components of Action Research considering teaching experience. Also, there is no difference in the teachers' attitudes to the necessity of methodological knowledge considering the variable education cycle. However, the differences are evident concerning the third variable - the number of seminars attended. The more seminars the respondents had attended, the more positive attitude they had to the necessity of methodological knowledge for conducting action researches. The applicable goal of this research may be reflected in the necessity to develop methodological knowledge and competences among both primary and secondary school teachers. The hypothesis is partially confirmed.

Cognition and metacognition in teaching is regarded as an important component of a successful design and realization of action researches. The research results showed that cognition and metacognition were more developed among primary school teachers. Moreover, this factor proved to be more developed among less experienced teachers than among their more experienced colleagues. It is, however, certain that a larger number of professional development seminars attended by teachers had a positive impact on cognition and metacognition. The applicable goal of this research: primary and secondary school teachers should have more positive attitudes to the components of cognition and metacognition in teaching. In addition, cognition and metacognition are to be present in the work of all teachers, regardless of their teaching experience. All teachers should be given the possibility to develop professionally in order to realize their teaching successfully, but also in order to be able to conduct action researches. The hypothesis that the teachers' responses will demonstrate a statistically significant difference regarding education cycle, teaching experience and the number of seminars attended, i.e. the independent research variables, is confirmed in full.

Reflexive practice and action researches as the components of education and teaching were most highly valued by primary school teachers. The applicable goal of this research: reflexive teaching for the purpose of action researches has to be understood as significant regardless of education cycle and teaching experience. Professional development is essential to the improvement of teachers even in this segment. The research proved the existence of statistically significant differences in the respondents' answers regarding education cycle and the number of seminars attended, but not regarding teaching experience, which means that his hypothesis is only partially confirmed.

Teachers need not only use other experts' researches and the results obtained from these professional studies. The factor Science education was valued more by the primary school teachers. The applicable goal of the research: teachers have to be trained and educated to conduct action researches, analyze and interpret research results, publish their papers presented at scientific conferences, regardless of education cycle and teaching experience. The teachers who attend professional development training can learn about the elements of Science education. This hypothesis is confirmed since the research results clearly show that there are statistically significant differences in the respondents' answers regarding education cycle, teaching experience and the number of seminars attended.

Teachers of various school subjects have to be innovative and eager to constantly learn something new, and improve themselves so as to go beyond their initial university education. Lifelong learning depends on education cycle, teaching experience or the number of seminars that teachers attend. The applicable goal of the research: teachers' competences have to be increased exclusively through innovative teaching methods and continuous improvement of teaching practice. It is concluded that this hypothesis is confirmed.

\section{Conclusions}

The theoretical and empirical benefits of action researches have been studied by numerous authors (Bolton, 2010; Burnaford, 2011; Burns, 2010; Elliot, 2007; Farrell, 2004; Jay and Johnson, 2002; Kayapinar, 2013; Kember, 2000; Lustic, 2009; McNiff and Whitehed, 2005; Noffke and Somekh, 2009; Vaughan and Burnaford, 2016; etc.). This research aimed to examine the components of action research present in the Serbian education system. The following are the results obtained in the course of this research.

Action researches represent a valid condition necessary for the improvement of teaching only if they are recognized and supported by the education system as a whole. Teachers who are willing to conduct action researches in their classrooms, who want to share the results of their researches with other teachers and constantly evaluate their teaching process are the action research teachers. Action researches are inseparable from teaching and they endow it with a higher level of quality.

The project to control and support action researches should be carried out systematically at each level of education system. Action researches encourage teachers to develop all aforementioned segments 
regardless of the determined independent research variables: education cycle, teaching experience and the number of professional development seminars attended. Action research help teachers to understand their own efficiency and which competences they should develop further. In fact, action researches sustain teaching competences and offer possibilities for the affirmation of teachers in science.

\section{Acknowledgements}

Prepared as a part of the project "Pedagogical Pluralism as the Foundation of the Education Strategy", financed by the Ministry of Education, Science and Technological Development of the Republic of Serbia (No. 179036, 2011-2021).

\section{Conflict of interests}

The authors declare no conflict of interest.

\section{References}

Balashov, E., Pasicichnyk, I. \& Kalamazh, R.(2021). Metacognitive awareness and academic self-regulation of HEI students, International Journal of Cognitive Research in Science, Engineering and Education (IJCRSEE), 9(2), 161-172. https:// doi.org/10.23947/2334-8496-2021-9-2-161-172

Bolton, G. (2010). Reflective practice: Writing and professional development. Thousand Oaks, CA: Sage. Retrieved from https://www.amazon.co.uk/Reflective-Practice-Gillie-Bolton/dp/184860212X

Burnaford, G. (2011). "Experienced Educators and Practitioner Research: The Challenge for University Graduate Programs," in Practitioner Research in Teacher Education: Theory and Best Practices, edited by I. M. Saleh and M. S. Khine, pp. 307-324. Emirates College for Advanced Education. United Arab Emirates \& Frankfurt: Peter. Retrieved from https:// www.perlego.com/book/1994918/practitioner-research-in-teacher-education-theory-and-best-practices-pdf

Burns, A. (2010). Doing action research in English language teaching: A guide for practitioners. New York: Routledge Retrieved from https://www.routledge.com/Doing-Action-Research-in-English-Language-Teaching-A-Guide-for-Practitioners/ Burns/p/book/9780415991452

Capone R., D'Acunto I., Del Sorbo M.R., Del Regno F. \& Tortoriello F. S. (2016). Action research: a new perspective in math and science education. New perspectives in science education. Italy: Universuty of Salerno. Retrieved from https://www. researchgate.net/publication/311734341_Action_research_a_new_perspective_in_math_and_science_education

Eilks, I. (2018). Action Research in Science Education: A twenty-years personal perspective. Action Research and Innovation in Science Education, 1(1), 3-14. https://doi.org/10.12973/arise/98909

Eilks, I., Naaman. M., R. \& Rauch, F. (2012). Action Research for innovations and Continuous Professional Development (CPD) in science education. In book: Inquiry-based science education in Europe: Reflections from the profile project Chapter: 3.7, Berlin. Retrieved from http://www.profiles-project.eu/res/Conference_2012/PROFILES_Book_final_October2012. pdf

Elliott, J. (2007). Reflecting where the action is: The selected works of John Elliott. London: Routledge. Retrieved from https://www. routledge.com/Reflecting-Where-the-Action-Is-The-Selected-Works-of-John-Elliott/Elliott/p/book/9780415369930

Farrell, T. S. C. (2004). Reflective practice in action. Thousand Oaks, CA: Corwin Press. Retrieved from https://us.corwin.com/ en-us/nam/book/reflective-practice-action

Fidelman, A. \& Capobianco, B. (2000). Action Research in Science Education. ERIC Clearinghouse for Science, Mathematics, and Environmental Education, 1-4. Retrieved from https://www.govinfo.gov/content/pkg/ERIC-ED463944/pdf/ERICED463944.pdf

Fulmer, G. W., Chu, H. E., \& Martin, S. N. (2018). The potential of teacher-led research: teachers' action research collaborations in science education in Singapore. Asia-Pacific Science Education, 4(7), 1-16. https://doi.org/10.1186/s41029-0180024-5

Glanz, J. (2016). Action Research by Practitioners: A Case Study of a High Schools attempt to Create Transformational Change. Journal of Practitioner Research, 1(1), 1-23. http://doi.org/10.5038/2379-9951.1.1.1027

Goodnough, K. (2003). Facilitating action research in the context of science education: reflections of a university researcher. Educational Action Research, 11(1), 41-64. http://doi.org/10.1080/09650790300200203

Hairon, S. (2017). Action research in Singapore: where are we now? Asia-Pacific Science Education, 3(1:5), 1-18. http://doi. org/1186/s41029-017-0016-x

Jay, J. K. \& Johnson, K. L. (2002). Capturing complexity: A typology of reflective practice for teacher education. Teacher and Teacher Education, 18, 73-85. Retrieved from https://teachsource.files.wordpress.com/2013/05/jay-and-johnson-onreflection.pdf

Kayapinar, U. (2013). Discovering expatriate reflective practitioners. Reflective Practice: International and Multidisciplinary Perspectives, 14(4), 435-451. http://doi.org/10.1080/14623943.2013.806297

Kavousi, F. (2016). Influence of Action Research on Meta-Cognitive Knowledge of Primary School Teachers in the Province of Alborz. International journal of humanities and cultural studies, 328-336, Tunisia: University of Gafsa. Retrieved from https://files.eric.ed.gov/fulltext/EJ1250763.pdf

Kember, D. (2000). Action Learning and Action Research: improving the quality of teaching and learning. London, Kogan Page. https://doi.org/10.4324/9780203016343

Lustick, D. (2009). The Failure of Inquiry: Preparing Science Teachers with an Authentic Investigation. Journal of Science Teacher Education, 20, 583-604. https://doi.org/10.1007/s10972-009-9149-4 
Osmanović-Zajić, J., Mamutović, A. \& Maksimović, J. (2021). The role of action research in teachers' professional development, International Journal of Cognitive Research in Science, Engineering and Education (IJCRSEE), 9(3), 301-317.

McNiff, J. \& Whitehead, J. (2005). Action Research for Teachers. London, Fulton. https://doi.org/10.4324/9780203462393

Noffke, S. \& B. Somekh (2009). Handbook of educational action research. London: Sage. https://dx.doi. org/10.4135/9780857021021

Tindowen, D. J., Guzman, J. \& Macanang, D. (2019). Teachers' Conception and Difficulties in Doing Action Research. Universal Journal of Educational Research, 7(8),1787-1794. http://doi.org/10.13189/ujer.2019.070817

Šteh, B., Kalin, J., \& Mažgon, J. (2021). Partnership Between Teachers and School Counsellors for Quality Learning and Work in the Community. International Journal of Cognitive Research in Science, Engineering and Education (IJCRSEE), 9(2), 147-159. https://doi.org/10.23947/2334-8496-2021-9-2-147-159

Vaughan, M. \& Burnaford, G. (2016). Action research in graduate teacher education: A review of the literature 2000-2015. Educational Action Research, 24(2), 280-299. https://doi.org/10.1080/09650792.2015.1062408 